\title{
Parathyroid Hormone-like Protein Is a Secretory Product of Atrial Myocytes
}

\author{
L. J. Deftos, D. W. Burton, and D. W. Brandt \\ Department of Medicine, University of California San Diego, and the San Diego Veterans Affairs Medical Center, \\ La Jolla, California 92161
}

\begin{abstract}
Parathyroid hormone-like protein (PLP) was originally identified from tumors associated with hypercalcemia. Recently, it has been found to be expressed in a stretch-responsive manner in several types of smooth muscle. We studied adult rat heart muscle for the presence of the PLP. Using immunohistology and the PCR, we demonstrated the presence of PLP and its mRNA in all heart chambers. Immunoelectron microscopy demonstrated PLP in secretory vesicles of atrial mycocytes. Using immunoassay, we demonstrated that atria contained a higher concentration of PLP than ventricles. Furthermore, primary cultures of both chambers released PLP into conditioned medium, with atria secreting more than ventricles. Considered with studies of the role of PLP in other tissues, our observations suggest that the production and secretion of PLP by cardiac myocytes represents a calcium-related regulatory function for this stretch-responsive polypeptide in the cardiovascular system. PLP in the heart may be the calcium counterpart for the atrial natriuretic-sodium regulatory axis of the cardiovascular system. (J. Clin. Invest. 1993. 92:727-735.) Key words: secretion • neuroendocrine $\bullet$ secretory granules $\bullet$ smooth muscle - cardiac muscle
\end{abstract}

\section{Introduction}

The parathyroid hormone-like protein (PLP) ${ }^{1}$ was originally discovered as a product of tumors associated with hypercalcemia (1-6). The subsequent development and application of immunochemical and nucleic acid probes for PLP have demonstrated its presence in a wide variety of normal tissues and organs (1-14). The most extensive expression has been in fetal tissues, but the presence of PLP in normal adult tissues has been noted for several organs $(8,13,14)$. Using immunoassay, immunohistology, and PCR, we have demonstrated the presence of PLP and its mRNA in cardiac myocytes. With immunoelectron microscopy, we have demonstrated that PLP is present in secretory vesicles of atrial cells.

\section{Methods}

Tissues. Fresh surgical specimens were collected from the heart of adult (100-150 g) rats ( Harlan Sprague-Dawley Inc., Indianapolis, IN). Por-

\section{Address correspondence to Dr. L. J. Deftos, 3350 La Jolla Village Drive, San Diego, CA 92161. \\ Received for publication 11 March 1993 and in revised form 21 April 1993.}

1. Abbreviations used in this paper: ANP, atrial natriuretic peptide; BNP, brain natriuretic peptide; PLP, parathyroid hormone-like protein.

The Journal of Clinical Investigation, Inc.

Volume 92, August 1993, 727-735 tions of the specimens were prepared for culture, PLP extraction, immunoassay, immunohistology, PCR, and immunoelectron microscopy, all with methods we have previously published (15-24).

Immunoassay. PLP was measured by two immunoassays that were conducted by modifications of previously described procedures (1519). Tyrosinated human PLP 1-34 and PLP 107-138 were used to prepare tracer by chloramine $T$ radioiodination and as respective assay standards, along with rabbit antisera to each of the respective peptides. Lack of cross-reaction in the assay for at least a 100 -fold excess was demonstrated for PTH 1-34, the noncorresponding PLP peptides, calcitonin, calcitonin gene-related peptide, chromogranin A, and for rat atrial and brain natriuretic peptides (ANP and BNP). All samples were assayed in multiple dilutions that paralleled the corresponding PLP standard. Control media (nonconditioned) did not react in the assay. The assay incubations were conducted under standard, nonequilibrium conditions, and the intra- and interassay variations were 7 and $12 \%$, respectively (15-19). All synthetic peptides were purchased from Peninsula Laboratories, Belmont, CA.

$m R N A$ studies. Fresh surgical specimens were processed into total RNA by extraction with RNAzol ${ }^{\mathrm{TM}}(20-22)$. Preparations of cDNA from the total RNA of the heart muscle were evaluated by PCR with primers for the coding region of PLP as previously described (22). PCR amplifications of cDNA samples were performed with $100 \mathrm{ng}$ RNA/ cDNA and a cycle program that consists of an initial melting step at $95^{\circ} \mathrm{C}$ for $2.5 \mathrm{~min}$, an annealing step of $55^{\circ} \mathrm{C}$ for $2 \mathrm{~min}, 30$ cycles with a melting step at $95^{\circ} \mathrm{C}$ for $30 \mathrm{~s}$, an annealing step at $55^{\circ} \mathrm{C}$ for $30 \mathrm{~s}$, and a primer extension step at $72^{\circ} \mathrm{C}$ for $45 \mathrm{~s}$. The program was complete after a 10-min final primer extension. Results of PCR amplifications were analyzed as previously described on $6 \%$ Tris-buffered EDTA acrylamide gels (22).

Immunohistology and electron microscopy. Immunohistology and immunoelectron microscopy were conducted on cardiac specimens as previously described with antibodies to human PLP1-34, 38-64, and 109-141 (15, 18, 19, 23, 24). Control studies for specificity were performed with irrelevant antibodies and with the test antibodies adsorbed with their antigen or control antigen (see figure legends for details). Whereas adsorption of antibodies with their corresponding peptide antigens blocked any positive immunohistological findings, adsorption with the previously indicated control peptides, including ANP and BNP, had no effect. Control, irrelevant antibodies (to salmon calcitonin) showed no reactivity.

Tissue incubation. Specimens of rat atria and ventricles were finely minced, dispersed, and incubated as primary cultures in minimal essential medium with $20 \%$ FBS $(15,16)$. After an overnight incubation, the media was changed and media samples were collected at the indicated times for PLP immunoassay, so that the PLP accumulated in the media for 18 and $44 \mathrm{~h}$, respectively (15-19).

\section{Results}

Our studies demonstrate the presence of PLP and its MRNA in adult rat heart muscles. Fig. 1 demonstrates the presence of PLP in heart muscle by immunohistology. PLP-containing cells are identified by antibodies that span the linear sequence of the molecule. The staining is diffuse in the atria but patchy in the ventricles, and we could not discern any differences between the staining and nonstaining cells in the latter. Fig. 2 shows the presence of PLP mRNA in heart as demonstrated by 

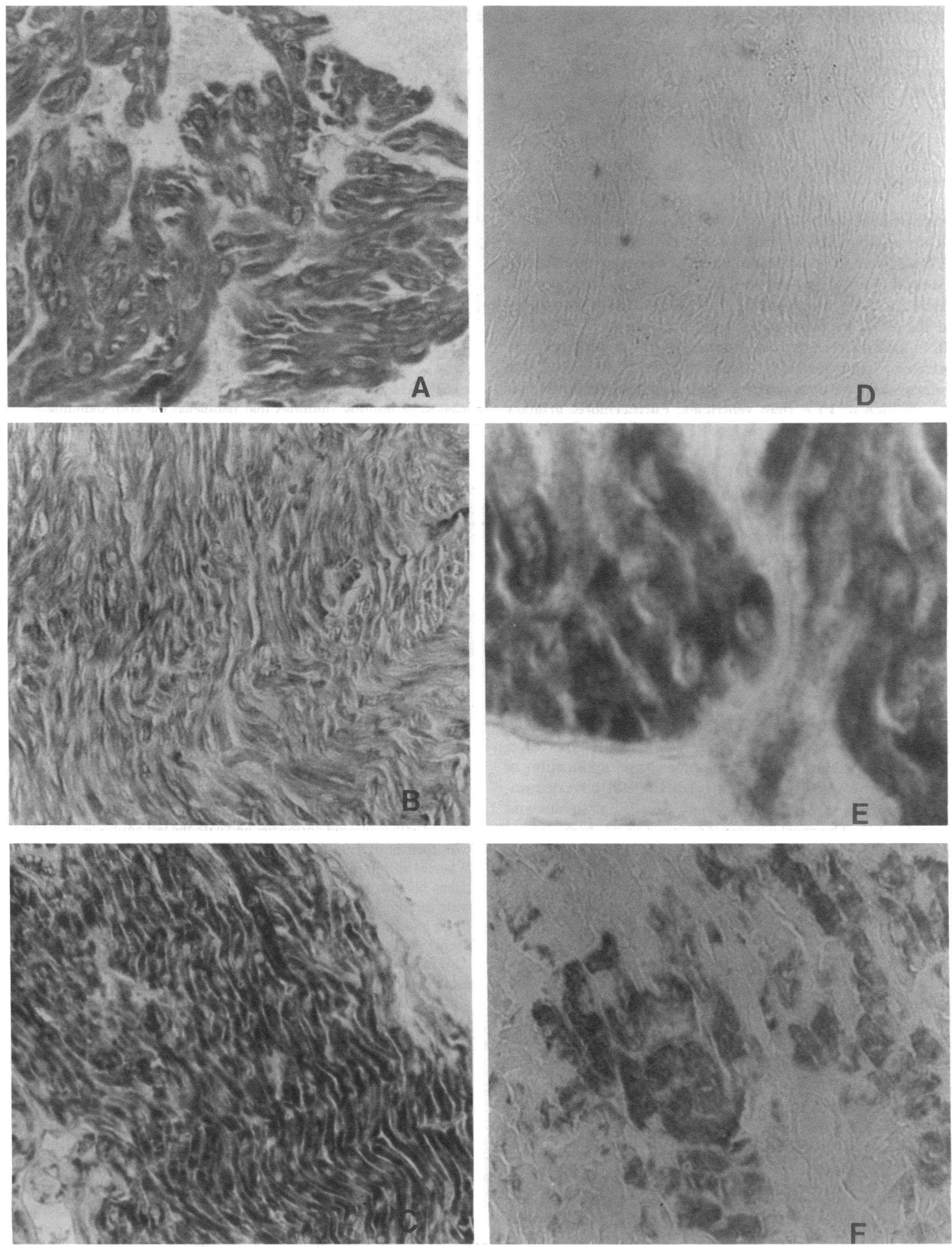


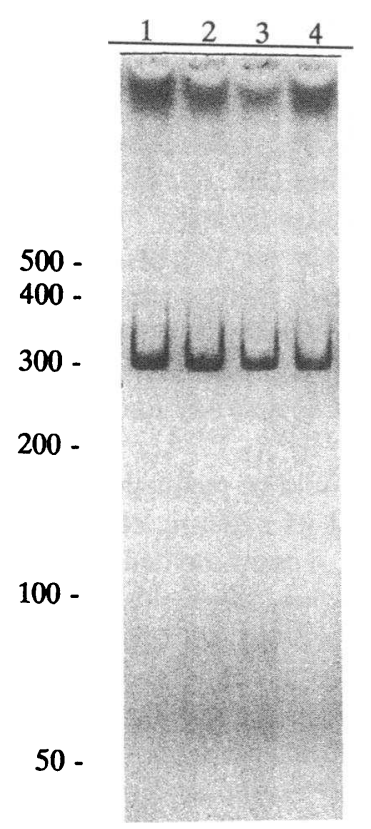

Figure 2. Demonstration by PCR of the presence of PLP-specific mRNA in heart muscle. PCR was conducted with cDNA prepared from total RNA. Lane 1, left ventricle. Lane 2, right ventricle. Lane 3, left atrium. Lane 4, right atrium. The migration positions of the molecular size standards are at the left. PCR reactions were performed with $100 \mathrm{ng}$ of RNA/cDNA. $10 \mu \mathrm{l}$ cDNA, $0.5 \mu \mathrm{M}$ primers, $10 \times$ Taq buffer (Promega Corp., Madison, WI ), $0.5 \mu \mathrm{Ci}\left[{ }^{32} \mathrm{P}\right] \mathrm{dCTP}$ (NEN, Boston, MA) and $2.5 \mathrm{U}$ Taq DNA polymerase (Promega Corp.) were added to each reaction. Amplification was performed in a thermal cycler (model 9600; Perkin-Elmer Cetus Instruments, Norwalk, CT). Dried gels were exposed to Kodak XAR film for 90 min. The $5^{\prime}$ primer was CTGGTTCAGCAGTGGAGCGTC; the $3^{\prime}$ primer was CCTGAGTTAGGGTATCTGCCCTGCCC. The predicted PCR product was 325 bp and spanned the linear sequence of rat PLP from -32 to +71 residues.

PCR. Although atrial and ventricular PLP mRNA were present in indistinguishable amounts in these qualitative studies, quantitative PCR studies will be necessary to demonstrate any differences between the chambers. Fig. 3 summarizes the immunoassays of PLP in extracts of heart muscle. PLP concentration was significantly higher in the atria than in the ventricles. Fig. 4 summarizes the immunoassays of media from incubations of heart muscle. Atria released more PLP into the media than ventricles. The differences in PLP concentrations in the two assays could be due to the immunochemical heterogeneity of PLP and/or the relative stability of each moiety under the specific experimental conditions $(1,2)$. Fig. 5 demonstrates the presence of PLP as immunogold particles in secretory vesicles of atrial myocytes. Only background staining was observed in other tissues, and PLP-containing secretory vesicles were not observed in control studies or in ventricles.

\section{Discussion}

Our studies demonstrate by immunochemical and nucleic acid probes the presence of PLP in adult rat heart (Figs. 1-3) and in atrial secretory vesicles (Fig. 5). PLP was originally discovered as a product of cancers associated with hypercalcemia (1-6).

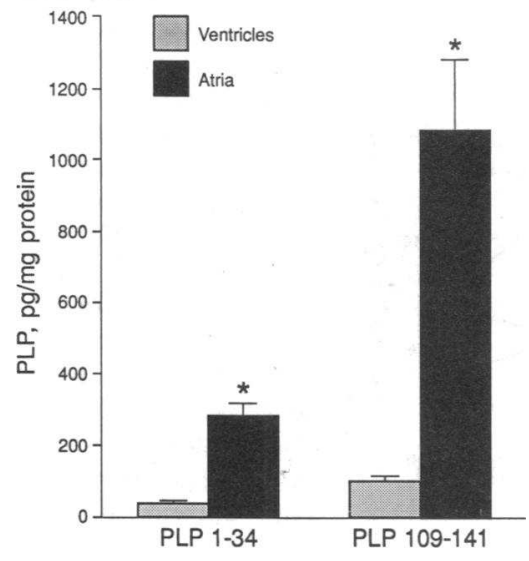

Figure 3. Concentration of PLP by immunoassay in chambers of rat heart (mean \pm SEM). Measurements were made in extracts of chambers from nine animals by the two immunoassay systems described in the text, one based on PLP1-34 (left panel, 20 chambers), the other on PLP109141 (right panel, 36 chambers). The concentrations in the atria were significantly $(P$

$<0.001)$ higher than in the atria. The concentrations in the ventricles were not significantly different from skeletal muscle ( $100 \pm 10 \mathrm{pmol} /$ $\mathrm{mg}$ protein). There were no significant differences between the left and right heart chambers.

Subsequent studies demonstrated the widespread production of PLP in fetal tissues $(8,13,14)$. These two early observations led to the consideration of PLP as an oncofetal protein (1). However, more extensive studies with improved methodologies continued to demonstrate PLP expression in some normal adult tissues, with the placenta as a notable example $(8-14,22$, 25 ). Many early studies of PLP production either did not include the heart or failed to demonstrate the polypeptide in this organ, although some studies did demonstrate low expression of PLP in heart $(1-6,12)$. By contrast, significant PLP production has been demonstrated by antibody and nucleic acid probes in several types of smooth muscle, including vascular, breast myoepithelial, urinary bladder, uterus, and avian oviduct (11, 26-31). A regulatory role for PLP at these muscle sites has been suggested by the observation that the production of PLP and/or its mRNA was increased by muscle stretch (26, 28 ). Correspondingly, receptor and end-organ studies demonstrated that PLP 1-34 was able to specifically bind to and relax smooth muscle or to inhibit its contraction (32-35).

Our findings of robust PLP expression in heart muscle are the first to demonstrate its presence there in secretory vesicles (36) (Fig. 5). Rather than the weak or variable expression of PLP previously observed in the heart, we found consistent and significant expression of the polypeptide in this organ. Our observations were made with antibody probes that span the linear sequence of PLP1-141. These observations suggest a local regulatory action for PLP in the heart. Direct evidence for a regulatory effect of PLP on cardiac function comes from the observations of Nickols et al. (37-39), who have shown that PLP administration increases heart rate, contractility, and coronary

Figure 1. Demonstration by immunohistology of PLP in rat heart muscle with three antibodies that span the linear sequence of the 1-141 residue molecule. The sections are not counterstained so that the dark-appearing immunoreactivity can be readily appreciated. $(A)$ Atrium stained with mouse monoclonal antibody 9H7 to PLP 109-141. Magnification, 588. (B) Atrium stained with rabbit antibody R760 to PLP 67-86. Magnification, 588. $(C)$ Atrium stained with mouse monoclonal antibody 8B12 to PLP1-34. Magnification, 558. (D) Preadsorbed control for panel $A$. $(E)$ High power view of panel $A$. Magnification, 2,350. $(F)$ Ventricles stained with antibody 9 H7. Magnification, 588 . The reaction is based on the hydrolysis of 5-bromo-4-chloro-3-indolyl phosphate and the reduction of nitroblue tetrazolium, producing a purple reaction product by streptavadin alkaline phosphatase, (Fisher Biotech, Pittsburgh, PA). Preabsorption of the antibodies with their respective antigens blocked the immunochemical staining, whereas preadsorption with at least a 100-fold molar excess of the noncorresponding peptides or rat ANP and BNP had no effect. The antibodies were used at dilutions of 1:100-1:1,000. There was no immunoreactivity when nonimmune serum or irrelevant (e.g., anti-salmon calcitonin) antibodies were used. 


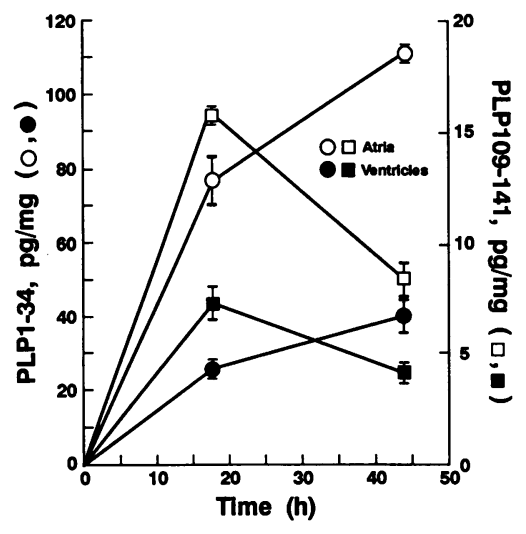

Figure 4. Release of immunoreactive PLP into conditioned medium by primary cultures of rat atria and ventricles as measured by immunoassays based on PLP134 (circles) and PLP109-141 (squares) Four chambers were finely minced and dispersed into 2-4 35- $\mathrm{mm}$ tissue culture cells with minimal essential medium supplemented with 20\% FBS. After 3

$\mathrm{d}$ of culture, the media were collected at the indicated time intervals for PLP radioimmunoassay. Atria released significantly $P<0.001$ more PLP than ventricles at each time point.

flow. It is notable that cardiovascular effects of PTH have been long appreciated (40-41). However, their physiological relevance had been questioned, since such large doses were necessary to demonstrate any actions. Since PTH and PLP seem to act via the same receptor, the previously reported PTH effects and the recently observed PLP effects may represent the same, or a closely related, direct regulatory effect on heart muscle mediated through the PTH/PLP receptor $(1,42)$. Such a pathway may be autocrine, paracrine, juxtacrine, or intracrine in nature, or any combination thereof.

A stretch signal for increased PLP production, well documented for smooth muscle, may also be present in heart muscle (26-30). In preliminary studies, we have demonstrated an increased concentration of PLP in the stretched, failing rat heart; however we have not as yet been able to identify a secretagogue for PLP (unpublished observations of the authors). Whereas stretch seems to be part of a positive regulatory pathway in smooth muscle, in that it increase PLP and PLP relaxes the muscle, increased production by stretch could represent a negative or counterregulatory pathway in cardiac muscle. This hypothesis would accommodate the observed stimulatory effect of PLP on the heart (37-39). The hypertrophy exhibited by the failing heart may be influenced by PLP production, since growth factor-like properties have also been observed for PLP in some studies $(1,43)$.
These observations regarding PLP in heart muscle are reminiscent of those relating to ANP and BNP, two other stretch-responsive peptides present in cardiac myocytes $(44,45)$. The distribution of PLP in various heart chambers (Figs. 1 and 3) roughly corresponds to the distribution of ANP and BNP in the heart. It is notable that in atrial secretory vesicles ANP is colocalized with chromogranin $\mathrm{A}$, a protein that is also colocalized with PLP at several neuroendocrine sites $(15,15,46)$. Even though there are no structural similarities between PLP and these two natriuretic molecules at either the amino acid or nucleotide level, their distribution pattern made it imperative for us to rule out any supurious immunochemical cross-reactivity between PLP and ANP or BNP for immunoassay and immunohistology studies, (Figs. 1, 3, and 4) and any nucleotide identity for PCR studies (Fig. 2).

The actions of PLP on the heart should be reconciled with its effects on other organ systems and its systemic effect on calcium and mineral homeostasis (47). A common denominator for all of these effects is calcium flux, transcellular and intracellular (1-6). The change in ambient calcium produced by PLP may initiate a tissue-specific cascade that leads to the respective and distinctive final action of PLP in each cell type, perhaps via the sarcoplasmic reticulum and actin-myosin complex in heart muscle (48). This view maybe too simplistic, however, because it considers only the well studied effect of the amino terminus of PLP and does not accommodate the growing body of evidence that PLP may be processed into peptides with unique biological actions (1-6). Tissue-specific mRNA splicing may further account for the diversity of the actions of PLP (20-22).

The presence of PLP in secretory vesicles of cardiac myocytes suggests an important regulatory role for the polypeptide in cardiovascular function (48). Further studies will be necessary to define conclusively its role in the normal heart. We have also demonstrated in preliminary studies the presence of PLP and for its mRNA in human, pig, and rabbit heart (unpublished observations of the authors). Additionally, PLP may participate in the stretch, hypertrophy, and corresponding oncofetal gene expression that is exhibited by the failing heart ( 49 , 50). It should be recalled that PLP 1-34 acts like PTH to decrease the renal clearance of calcium $(1,41)$. Thus, PLP could represent a second stretch-responsive regulatory axis in cardiac function that, in contrast to ANP and BNP, subserves calcium rather than sodium translocation. These two regulatory systems may also function in the utero-placental complex to regu-

Figure 5. The demonstration by electron microscopic immunocytochemistry of PLP in secretory vesicles of the rat atria. Monoclonal antibody 9H7 was used in an immunogold format. This antibody was selected because of its consistent performance in non-electron microscopy (light level) immunohistology studies. Random areas of rat cardiac muscle were surgically removed and fixed in $3.0 \%$ paraformaldehyde, $1.0 \%$ glutaraldehyde, in $0.1 \mathrm{M}$ sodium cacodylate buffer, $\mathrm{pH}$ 7.4. Tissues were then incubated in $100 \mathrm{mM}$ glycine in sodium cacodylate buffer followed by dehydration in a graded series of ethanol solutions. Embedding and polymerization were conducted in LR white resin (medium grade; Ted Pella Inc., Redding, California). Thin sections $\left(60-90 \mathrm{~A}^{\circ}\right)$ were placed on nickel grids coated with a $0.5 \%$ parlodian film. Grids were incubated with $20 \mu \mathrm{g} / \mathrm{ml}$ ligand affinity purified monoclonal antibody $9 \mathrm{H} 7$ to PLP $109-141$ in Tris-buffered saline, $0.8 \%$ BSA, $0.1 \%$ gelatin, and $0.01 \%$ azide. Control grids were incubated with antibody after absorption for $24 \mathrm{~h}$ with $3 \mu \mathrm{g} / \mathrm{ml}$ of its antigen, PLP 109-141, or in buffer without the primary antibody. After incubation and washing, the samples were transferred to a 1:10 dilution of protein A conjugated to $15 \mathrm{~nm}$ colloidal gold (E-Y Laboratories, San Mateo, CA). Samples were then fixed in $2 \%$ glutaraldehyde and poststained with $2 \%$ aqueous uranyl acetate followed by bismuth subnitrate. Examination was with a Zeiss EM10B electron microscope.

The dark granules within the secretory vesicles correspond to the electron-dense gold particles. No specific granules were seen in any other locations, although occasional background granules could be observed. Adsorption of the antibody with its peptide blocked immunoreactivity, and there was no immunoactivity with an irrelevant antibody and without the primary antibody. PLP could not be demonstrated in secretory vesicles in the ventricle. Magnification: 5A-17,325; 5B-110,250; 5C-320,000. 


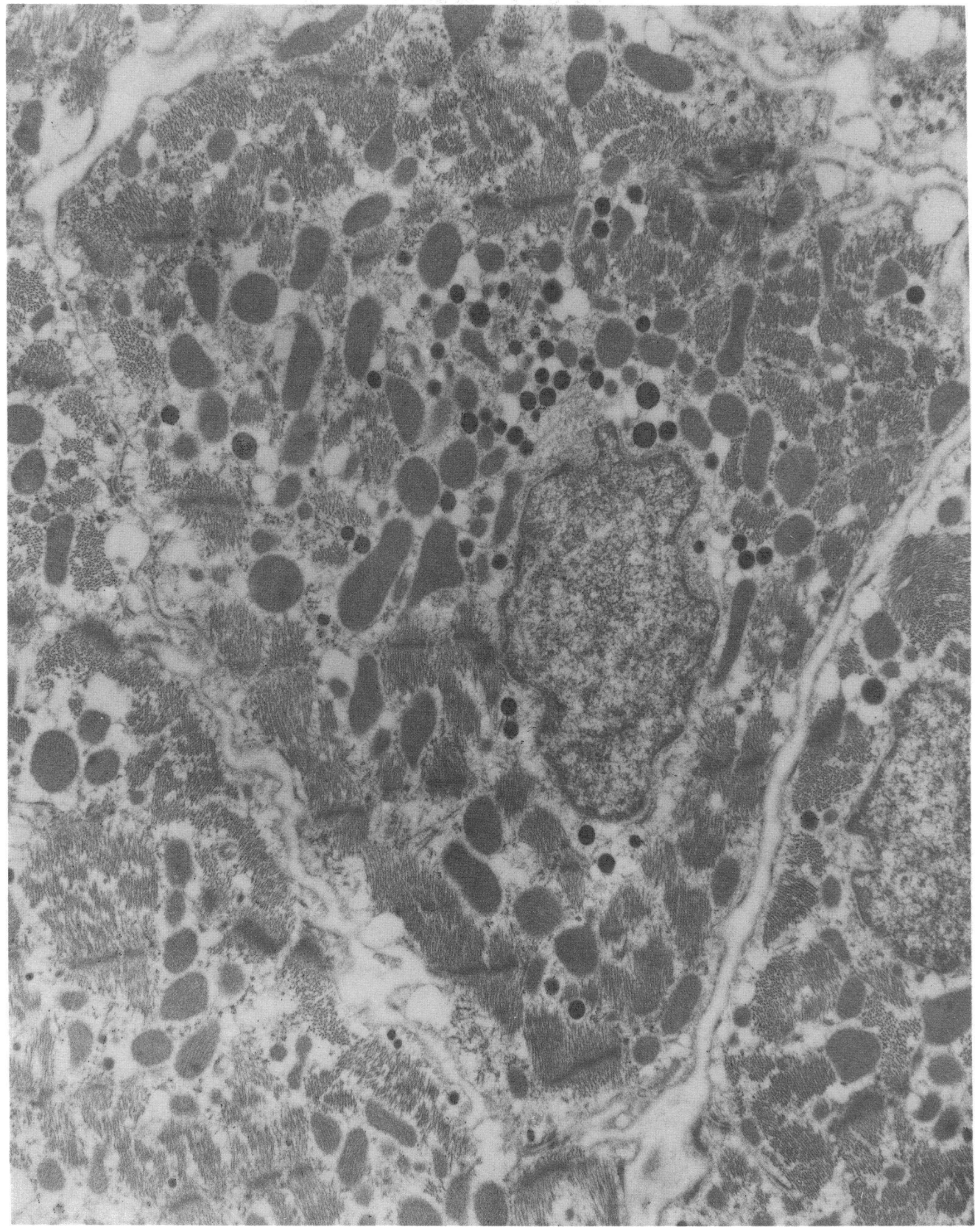




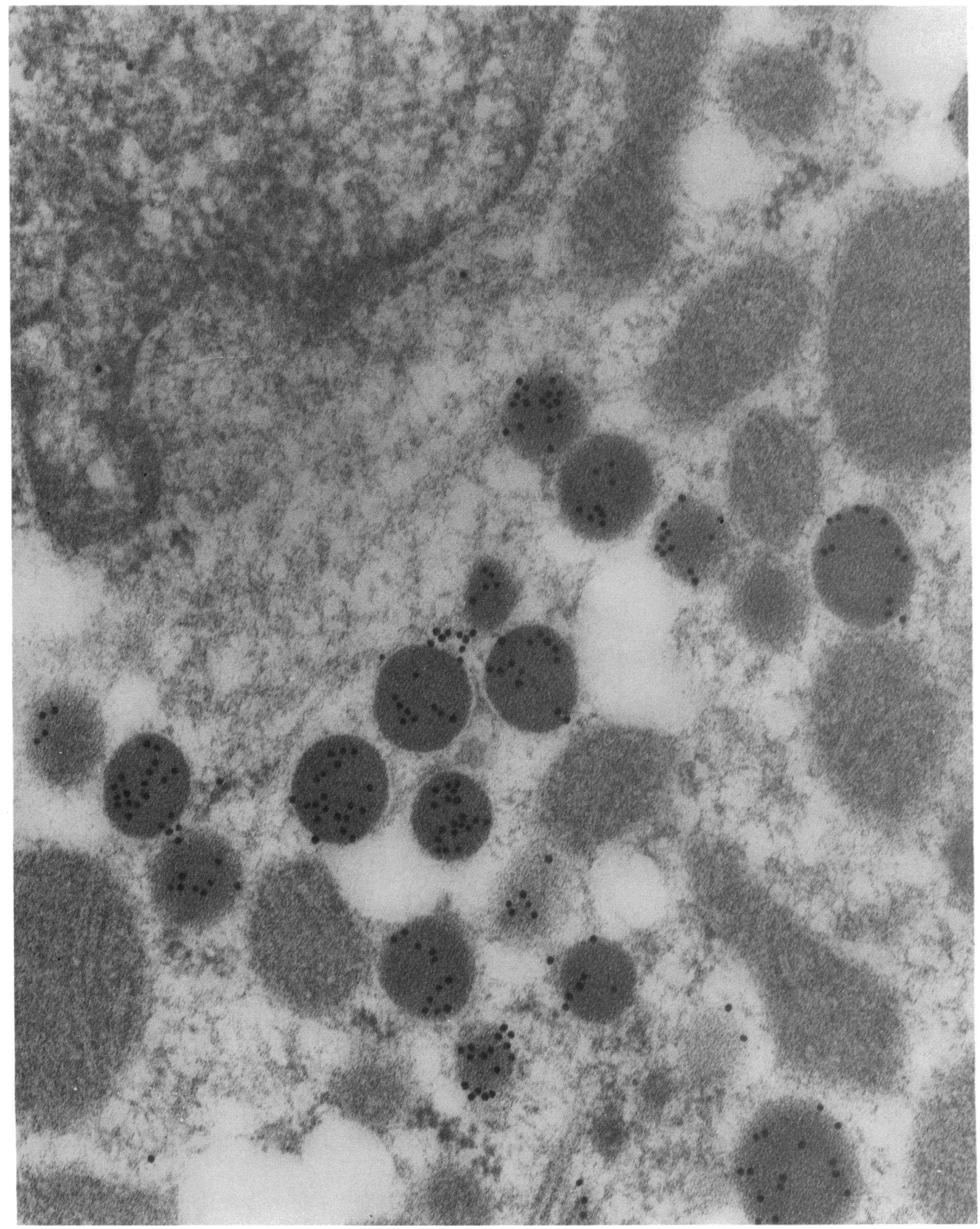

Figure 5. (Continued) 


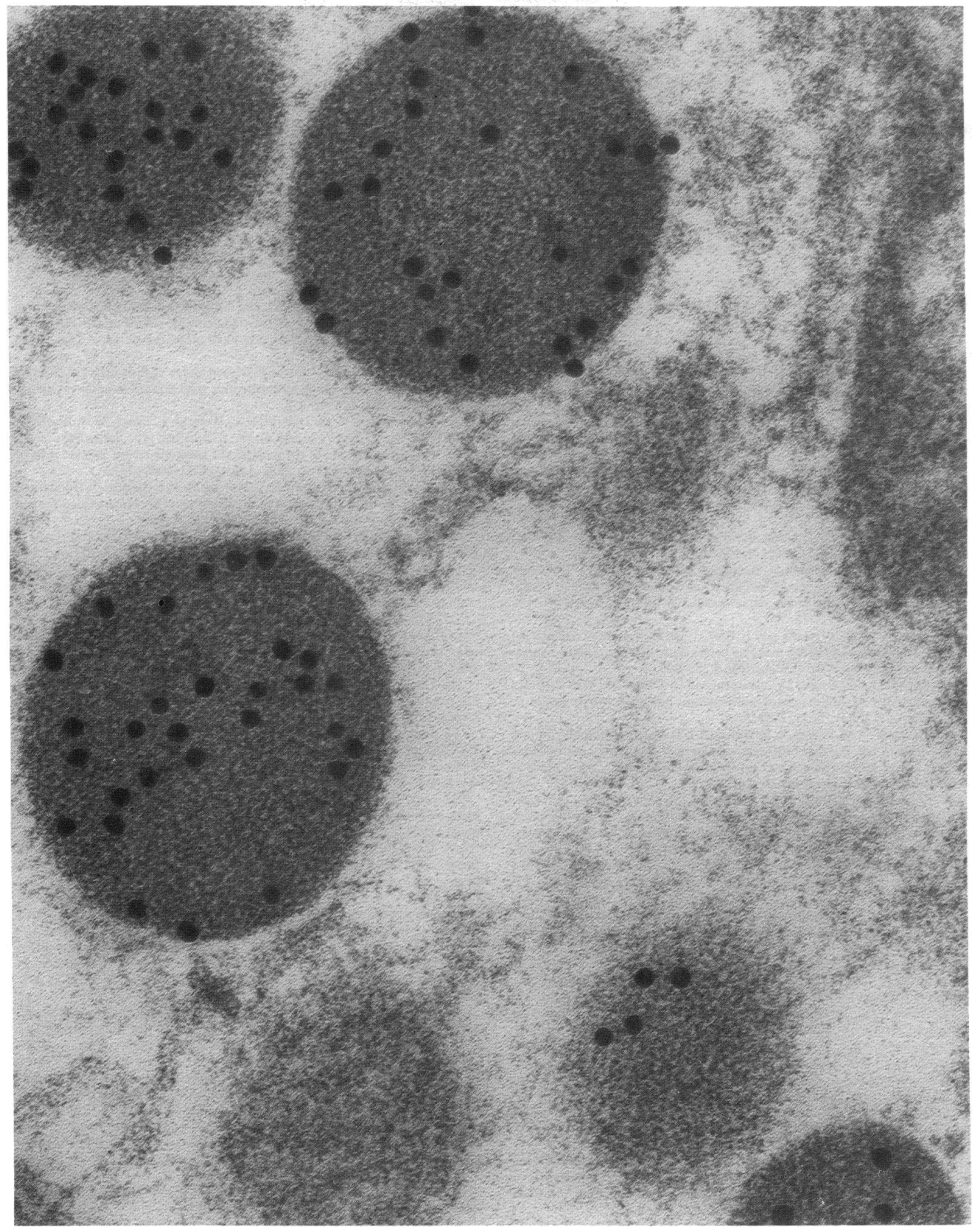

Figure 5. (Continued) 
late blood flow (50). The presence in heart of a PLP-calcium axis that corresponds to an ANP/BNP-sodium axis may explain some aspects of the role of both of these two ions in hypertension and congestive heart failure (51-53).

\section{Acknowledgments}

Cheryl Chalberg and Kathy Smith assisted with the immunoassays. AbbeyAnn Sisk, P. L. Reid and Jerry Vande Berg assisted with the EM studies. Rhonda Mills assisted with the preparations of the manuscript.

This work was supported by the National Institutes of Health, the National Cancer Institute, and the Department of Veterans Affairs.

\section{References}

1. Stewart, A. F., and A. E. Broadus. 1990. Parathyroid hormone-related proteins: Coming of age in the 1990s. J. Clin. Endocrinol. Metab. 71:1410-1414.

2. Martin, T. J., J. M. Moseley, and M. T. Gillespie. 1991. Parathyroid hormone-related protein. Biochemistry and molecular biology. Crit. Rev. Biochem. Mol. Biol. 26:377-395.

3. Goltzman, D., G. N. Hendy, and D. Banville. 1989. Parathyroid hormonelike peptide: molecular characterization and biological properties. Trends Endocrinol. Metab. 1:39-44.

4. Stewler, G. J., and R. A. Nissenson. 1990. Peptide mediators of hypercalcemia in malignancy. Annu. Rev. Med. 41:35-44.

5. Singer, F. R. 1990. Parathyroid hormone-related protein. Mayo Clin. Proc. 65:1502-1505.

6. Bilezikian, J. P. 1990. Parathyroid hormone-related peptide in sickness and in health. N. Engl. J. Med. 322:1151-1153.

7. Yasuda, T., D. Banville, S. A. Rabbani, G. N. Hendy, and D. Goltzman. 1989. Rat parathyroid hormone-like peptide: comparison with the human homologue and expression in malignant and normal tissue. Mol. Endocrinol. 89:518525.

8. Senior, P. V., D. A. Heath, and F. Beck. 1990. Expression of parathyroid hormone-related protein mRNA in the rat before birth: demonstrated by hybridization histochemistry. J. Mol. Endocrinol. 6:281-290.

9. Asa, S. L., J. Henderson, D. Goltzman, and D. J. Drucker. 1990. Parathyroid hormone-like peptide in normal and neoplastic human endocrine tissues. $J$. Clin. Endocrinol. Metab. 71:1112-1118.

10. Kitazawa, S., M. Fukase, R. Kitazawa, A. Takenaka, A. Gotoh, T. Fujita, and S. Maeda. 1990. Immunohistologic evaluation of parathyroid hormone-related protein in human lung cancer and normal tissue with newly developed monoclonal antibody. Cancer (Phila.). 67:984-989.

11. Kramer, S., F. H. Reynolds, Jr., M. Castillo, D. M. Valenzuela, M. Thorikay, and J. M. Sorvillo. 1991. Immunological identification and distribution of parathyroid hormone-like protein polypeptides in normal and malignant tissues. Endocrinology. 128:1927-1937.

12. Selvanayagam, P., K. Graves, C. Cooper, and S. Rajaraman. 1991. Expression of the parathyroid hormone-related peptide gene in rat tissue. $L a b$. Invest. 64:713-717.

13. Campos, R. V., S. L. Asa, and D. J. Drucker. 1991. Immunocytochemical localization of parathyroid hormone-like peptide in the rat fetus. Cancer Res. 51:3651-6357.

14. Burton, P. B. J., C. Moniz, P. Quirke, A. Malik, T. D. Bui, H. Juppner, G. V. Segre, and D. E. Knight. 1992. Parathyroid hormone-related peptide: expression in fetal and neofetal development. J. Pathol. 167:291-296.

15. Deftos, L. J., A. F. Gazdar, K. Ikeda, and A. E. Broadus. 1989. The parathyroid hormone-related protein associated with malignancy is secreted by neuroendocrine tumors. Mol. Endocrinol. 3:503-508.

16. Deftos, L. J., R. Hogue-Angeletti, C. Chalberg, and S. Tu. 1989. PTHrP secretion is stimulated by CT and inhibited by $\mathrm{CgA}$ peptides. Endocrinology. 125:563-566.

17. Brandt, D. W., S. J. Pandol, and L. J. Deftos. 1991. Calcium-stimulated parathyroid hormone-like protein (PLP) secretion: potentiation through a protein kinase-C pathway. Endocrinology. 128:2999-3004.

18. Martin, E. M. E., V. E. Gould, A. Hoog, S. T. Rosen, J. A. Radosevich, and L. J. Deftos. 1991. Parathyroid hormone-related protein, chromogranin A and calcitonin gene products in the neuroendocrine skin carcinoma cell lines MKL-1 and MKL-2. Bone Miner. 14:114-120.

19. Brandt, D. W., D. W. Burton, A. F. Gazdar, H. E. Oie, and L. J. Deftos. 1991. All major lung cancer cell types produce parathyroid hormone-like protein: heterogeneity assessed by high performance liquid chromatography. Endocrinology. 129:2466-2470.

20. Ikeda, K., E. C. Weir, M. Mangin, P. S. Dannies, B. Kinder, L. J. Deftos, E. M. Brown, and A. E. Broadus. 1988. Expression of messenger RNAs encoding a parathyroid hormone-like peptide in normal human and animal tissues with abnormal expression in human parathyroid adenomas. Mol. Endocrinol. 2:1230 1236.

21. Lu, C., K. Aceto, L. J. Deftos, A. F. Gazdar, M. Mangin, and A. E. Broadus. 1989. Glucocorticoid regulation of parathyroid hormone-related peptide gene transcription in a human neuroendocrine cell line. Mol. Endocrinol. 3:2034-2040.

22. Brandt, D. W., M. E. Burns, D. E. Bruns, J. E. Ferguson II, D. W. Burton, and L. J. Deftos. 1992. The parathyroid hormone-related protein (PTHrP) gene preferentially utilizes a gc-rich promoter and the PTHrP 1-139 coding pathway in normal human amnion. Biochem. Biophys. Res. Commun. 189:938-943.

23. McMillan, P. J. J., R. A. Dewri, E. E. Joseph, R. L. Schulta, and L. J. Deftos. 1989. Rapid changes of light microscopic indices of osteoclast-bone relationships correlated with electron microscopy. Calcif. Tissue Int. 44:399-405.

24. Cooper, D. N. W., P. L. Haywood-Reid, W. R. Springer, and S. H. Barondes. 1986. Bacterial glycoconjugates are natural ligands for the carbohydrate binding site of discoidin I and influence its cellular compartmentalization. Dev. Biol. 114:416-425.

25. Casey, M. L., M. Mibe, A. Erk, and P. C. MacDonald. 1992. Transforming growth factor- $\beta_{1}$ Stimulation of parathyroid hormone-related protein expression in human uterine cells in culture: mRNA and protein secretion. J. Clin. Endo crinol. \& Metab. 74:950-952.

26. Daifotis, A. G., E. C. Weir, B. E. Dreyer, and A. E. Broadus. 1992. Stretchinduced parathyroid hormone-related peptide gene expression in the rat uterus. J. Biol. Chem. 267:23455-23458.

27. Thiede, M. A., A. G. Daifotis, E. C. Weir, M. L. Brines, W. J. Brutis, K. Ikeda, B. E. Dreyer, R. E. Garfield, and A. E. Broadus. 1990. Intrauterine occupancy controls expression of the parathyroid hormone-related peptide gene in preterm rat myometrium. Proc. Natl. Acad. Sci. 87:6969-6973.

28. Thiede, M. A., S. C. Harm, R. L. McKee, W. A. Grasser, L. T. Duong, and R. M. Leach, Jr. 1991. Expression of the parathyroid hormone-related protein gene in the avian oviduct. Endocrinology. 129:1958-1966.

29. Hongo, T., J. Kupfer, H. Enomoto, B. Sharif, D. Giannella-Neto, J. S. Forrester, F. R. Singer, D. Goltzman, G. N. Hendy, C. Pirola, J. A. Fagin, and T. L. Clemens. 1991. Abundant expression of parathyroid hormone-related protein in primary rat aortic smooth muscle cells accompanies serum-induced proliferation. J. Clin. Invest. 88:1841-1847.

30. Yamamoto, M., S. C. Harm, W. A. Grasser, and M. A. Thiede. 1992. Parathyroid hormone-related protein in the rat urinary bladder: a smooth muscle relaxant produced locally in response to mechanical stretch. Proc. Natl. Acad. Sci. USA. 89:5326-5530.

31. Thiede, M. A., and G. A. Rodan. 1988. Expression of a calcium mobilizing parathyroid hormone-like peptide in lactating mammary tissue. Science (Wash. DC). 242:278-280.

32. Mok, L. L. S., E. Ajiwe, J. Martin, J. C. Thompson, and C. W. Cooper. 1989. Parathyroid hormone-related protein relaxes rat gastric smooth muscle and shows cross-desensitization with parathyroid hormone. J. Bone Miner. Res. 4:433-439.

33. Mok, L. L. S., C. Cooper, and J. C. Thompson. 1989. Parathyroid hormone and parathyroid hormone-related protein inhibit phasic contraction of pig duodenal smooth muscle. Proc. Soc. Exp. Biol. Med. 191:337-340.

34. Shew, R. J., J. A. Yee, D. B. Kliewer, Y. J. Keflemariam, and D. L. McNeill. 1991. Parathyroid hormone-related protein inhibits stimulated uterine contraction in vitro. J. Bone Miner. Res. 6:955-959.

35. Barri, M. E. S., S. K. Abbas, and A. D. Care. 1992. The effects in the rat of two fragments of parathyroid hormone-related protein on uterine contractions in situ. Exp. Physiol. 77:481-490.

36. Singer, F. R., and L. Liang. 1992. Parathyroid hormone related protein localized in secretory granules of Rice 500 Leydig cell tumor cells. In Proceedings of the 74th Annual Meeting of the Endocrine Society, San Antonio, TX. p. 209. (Abstr.)

37. Nickols, G. A., A. D. Nana, M. A. Nickols, D. J. DiPette, and G. K. Askimakis. 1989. Hypotension and cardiac stimulation due to the parathyroid hormone-related protein, humoral hypercalcemia of malignancy factor. Endocrinology. 125:834-841.

38. Nickols, G. A., M. A. Nickols, and J. J. Helwig. 1990. Binding of parathyroid hormone and parathyroid hormone-related protein to vascular smooth muscle of rabbit renal microvessels. Endocrinology. 126:721-727.

39. Roca-Cusachs, A., D. J. DiPette, and G. A. Nickols. 1991. Regional and systemic hemodynamic effects of parathyroid hormone-related protein: preservation of cardiac function and coronary and renal flow with reduced blood pressure. J. Pharmacol. Exp. Ther. 256:110-256.

40. Charbon, G. A. 1968. A rapid and selective vasodilator effect of parathyroid hormone. Eur. J. Pharmacol. 3:275-278.

41. Pang, O. K. T., H. F. Janssen, and J. A. Yee. 1980. Effects of synthetic parathyroid hormone on vascular beds of dogs. Pharmacology. 21:213-222.

42. Thiede, M. A., D. N. Petersen, W. A. Grasser, H. Jüppner, A. B. AbouSamra, and G. V. Segre. 1992. Coexpression of PTHrP and PTH/PTHrP receptor mRNA in vasculature supports a local mechanism of actions in cardiovascular tissues. J. Bone Miner. Res. 7:S240. (Abstr.) 
43. Insogna, K. L., A. F. Stewart, C. A. Morris, L. M. Hough, L. M. Milstone, and M. Centrella. 1989. Native and a synthetic analogue of the malignancy-associated parathyroid hormone-like protein have in vitro transforming growth factor like properties. J. Clin. Invest. 83:1057-1060.

44. Atlas, S. A., and J. H. Laragh. 1990. Atrial natriuretic factor and its involvement in hypertensive disorders In Hypertension: Pathophysiology, Diagnosis, and Management. Vol. 1. J. H. Laragh and B. M. Brenner, editors. Raven Press, Ltd., New York. 861-883.

45. Mukoyama, M., K. Nakao, K. Hosoda, S. I. Suga, Y. Saito, Y. Ogawa, G. Shirakami, M. Jouasaki, K. Obata, H. Yasue, et al. 1991. Brain natriuretic peptide as a novel cardiac hormone in humans. J. Clin. Invest. 87:1402-1414.

46. Steiner, H. J., R. Weiler, C. Ludescher, K. W. Schmidt, and H. Winkler. 1990. Chromogranins A and B are co-localized with artial natriuretic peptides in secretory granules of rat heart. J. Histochem. Cytochem. 38:845-850.

47. Burtis, W. J. 1992. Parathyroid hormone-related protein. Structure, function and measurement. Clin. Chem. 38:2171-2183.
48. Dzau, V. J. 1992. Autocrine and paracrine mechanisms in the pathophysiology of heart failure. Am. J. Cardiol. 70:4C-11C.

49. Frohlich, E. D., A. V. Chobanian, R. B. Devereux, H. P. Dustan, V. Dzan, F. Fauad-Tarazi, M. J. Horan, M. Marcus, B. Massie, M. A. Pfeffer, et al. 1992. The heart in hypertension. N. Engl. J. Med. 327:998-1008.

50. Prada, J. A., R. Ross, and K. E. Clark. 1992. Effect of atrial natriuretic peptide and other vasoactive compounds on the uterine vascular bed of the nonpregnant sheep. Proc. Soc. Exp. Biol. Med. 201:261-266.

51. McCarron, D. A., R. J. Sheneidman, and D. M. Lee. 1987. $\mathrm{Ca}^{2+}$ defects in experimental hypertension: SHR's renal response to chronic infusion of human PTH (1-34). Kidney Int. (Suppl. 22) 32:S249-S253.

52. Stern, N., D. B. N. Lee, V. Silis, F. W. J. Beck, L. J. Deftos, and J. R. Sowers. 1984. Effects of high calcium intake in blood pressure and calcium metabolism in young SHR. Hypertension (Dallas). 6:639-646.

53. DiPette, D. J., W. Christenson, M. A. Nickols, and G. A. Nickols. 1992. Cardiovascular responsiveness to parathyroid hormone (PTH) and PTH-related protein in genetic hypertension. Endocrinology. 130:2045-2051. 